\title{
Para além do "voto de sangue": escolhas populares e liderança política carismática na Baixada Fluminense. $O$ caso Joca
}

\author{
Linderval Augusto Monteiro ${ }^{1}$
}

\begin{abstract}
RESUMO
Partindo do processo de mitificação política do primeiro prefeito de Belford Roxo (RJ), este artigo apresenta a trajetória política de Jorge Júlio Costa dos Santos (Joca), tomando como base as maneiras próprias de a população da Baixada Fluminense organizar-se com a finalidade de resolver os vários problemas originários da pequena presença pública existente desde o início da colonização proletária da região e que catalisou as emancipações distritais dos anos iniciais da década de 1990, inauguradoras daquilo que chamo liderança marginal carismática em oposição às elites que tradicionalmente controlavam os governos executivos e as casas legislativas da região.
\end{abstract}

Palavras-chave: invisibilidade social; violência urbana; cidadania.

\begin{abstract}
Starting from the process of political performance of first mayor of Belford Roxo (RJ), this article shows the political trajectory of Jorge Julio Costa dos Santos (nickname Joca) taking into consideration the own manners of Baixada Fluminense people organized with purpose of resolving the various problems originated from small public presence since the beginning of worker colonization from the region and who got together the emancipations district from first decades of 90's, they were the first charismatic deprived leadership in opposition elites who traditionally controlled the executive governments and legislatures of the region.
\end{abstract}

Keywords: Social invisibility; urban violence; citizenship.

\footnotetext{
${ }^{1}$ Professor adjunto da Faculdade de Ciências Humanas da Universidade Federal da Grande Dourados (MS).
} 


\section{Introdução}

A morte é, invariavelmente, um dos momentos mais marcantes na trajetória de alguns personagens. Esquecem-se aí diversas características - geralmente as negativas da vida dos homens, passando-se a construir uma segunda pessoa, essa sempre ideal, em um processo de mitificação, tão corriqueiro no mundo ocidental que se pode pensar ser ele um dos grandes responsáveis pela criação de heróis diversos destinados geralmente a representar esperanças perdidas ou exemplos a seguir.

Entende-se que a mitificação, por maior que seja o carisma do defunto, é sempre algo conduzido por um grupo que o admirava em vida e que, exatamente por isso, sentese na obrigação de não deixar sua memória desaparecer e, indo além, de retocar seu retrato através da pintura de novos detalhes, sempre ideais e mais fáceis de fazer, uma vez que construídos distantes de quem mais poderia anuviar o novo retrato: o morto.

Em resumo, a morte corresponde a um momento supremo de construção e retoque de memórias, sendo óbvio pensar que tais memórias deverão variar de acordo com o morto. Ser o morto um homem público carismático pode equivaler à construção de memórias conflitantes, afinal muito provavelmente personagens de tal tipo juntam em torno de si grupos diversos, e as disputas entre os membros desses grupos pode equivaler à criação de retratos diversos, por vezes opostos.

O personagem sobre a vida e morte do qual nos debruçaremos abaixo foi um líder apressado e contraditório que, atuando em Belford Roxo, transformou-se em um mito político para a população desse município.

Seguir sua ascensão até ao cargo político máximo de seu município pressupõe que consideramos ser ele o melhor representante de um tipo particular de liderança que, embora possa parecer solitário, gravita em torno das maneiras "escolhidas" pela população local para relacionar-se com o poder público e com as dificuldades cotidianas encontradas pelos que ocupam a região da Baixada Fluminense.

Iniciar a descrição de sua vida exatamente pelo final desta prende-se a uma necessidade de ordem prática: nesse momento podemos encontrar o líder carismático muito próximo da massa belford-roxense que, em outros momentos, pareceria submetida a ele. Dizendo-se de outra forma: a passividade de um morto pode servir-nos para definir mais claramente a simbiose que existiu entre Joca e a população de Belford Roxo. Inici- 
ar a descrição dessa vida em outro momento provavelmente não daria a este texto o tom que desejo que ele tenha: o de uma união entre líder e massa popular.

\section{Uma morte inevitável?}

Não era difícil imaginar que Joca acabaria a sua vida assassinado, afinal ele era considerado participante de grupos de extermínio, assaltante, traficante de drogas e receptor de cargas roubadas. ${ }^{2}$

Sendo famosa sua falta de medidas, mobilizava grande quantidade de seguranças a fim de proteger-se, mas acumulava desafetos, esbofeteando opositores políticos em pleno centro da cidade de Belford Roxo ou participando de ataques armados à casa de vereadores que teimassem em não pensar segundo as suas "sugestões".3

Se a morte violenta era previsível, ela ocorreu, entretanto, no momento em que ninguém esperava: Joca estava no auge de seu governo e, talvez por causa da quantidade de seguranças ou devido às duas pistolas que se gabava de portar, era difícil imaginar o primeiro prefeito de Belford Roxo abatido por onze tiros dados durante um assalto mal sucedido ocorrido quando ele e outros prefeitos da Baixada encaminhavam-se para uma reunião com o governador fluminense Marcello Alencar. ${ }^{4}$

Enfim, é preciso manter-se preso a algo concreto e o fato é que ele, aproximadamente às $18 \mathrm{~h} 30 \mathrm{~min}$ do dia 20 de junho de 1995, foi assassinado após reagir a um assaltante apelidado de Ratinho (apelido provavelmente proveniente do pequeno tamanho do ladrão) que, atraído pelo grosso colar e pulseira de ouro do prefeito, aproximou-se do carro dirigido por Joca quando este parou em um engarrafamento próximo ao túnel Santa Bárbara. Segundo o então prefeito de São João de Meriti - que viajava ao seu lado e tinha a perna imobilizada, conseguindo mesmo assim afastar-se do local do crime enquanto os tiros eram disparados -, Joca recusou-se a entregar suas joias ao bandido, tentou abrir a porta do carro e utilizar suas armas ao mesmo tempo. O bandido impressionado com o tamanho de Joca, "assustou-se" e descarregou uma pistola no corpo do

\footnotetext{
${ }^{2}$ A forma pela qual Joca conseguiu enriquecer não é muito clara. Em entrevistas dizia ter sido baleiro em trens, carroceiro, cobrador e motorista de ônibus, lutador de luta livre, até ter se transformado em empresário do ramo de transportes e material de construção. Como não existiu uma maneira de investigar isso sem correr riscos, preferimos conformarmo-nos com as versões divulgadas pela imprensa local que falam de uma transformação rápida de Joca em empresário bem sucedido. Os meios utilizados por ele para chegar a isso (trabalho, apara de cargas roubadas etc.) não sabemos.

3 A.D.F. Entrevista Concedida em 09 set. 1995.

${ }^{4}$ Especula-se atualmente na região da Baixada que a reunião com Marcello Alencar trataria do afastamento do deputado federal Nelson Bornier do cargo de secretário especial da Baixada.
} 
prefeito que morreu instantaneamente, ficando estendido no asfalto à mercê de curiosos ${ }^{5}$ tal como dezenas de corpos que todos os dias eram abandonados na Baixada Fluminense, considerada por um dos prefeitos dessa região um "estado cujo governador é Joca". 6

Algumas horas mais tarde (três horas da madrugada do dia seguinte) uma equipe do jornal $O$ Dia, chegando ao centro de Belford Roxo, encontrou uma multidão concentrada na Praça Eliakim Batista, que é a principal do pequeno centro municipal. Incentivada por um dos filhos de Joca, a multidão atacou a equipe desse jornal que era acusado de ter tirado fotos de Joca assassinado enquanto a perícia policial realizava seus trabalhos estando Joca somente de sunga. A multidão apoderou-se do equipamento dos jornalistas os quais somente deixaram de ser agredidos devido à interferência de alguns conhecidos políticos e jornalistas locais que impediram o pior colocando-se entre a multidão enfurecida e a equipe do jornal carioca. ${ }^{7}$

A imprensa local calculou que, na madrugada do dia 21 de junho, mais de cem mil pessoas concentravam-se na praça central do município esperando pelo corpo de Joca. É significativo verificar como a população lamentava-se pelo prefeito morto: é certo que um ar de perplexidade pairava sobre aquela multidão que tentava localizar dentro das informações desencontradas um culpado pelo ultraje ao seu líder.

Não existia certeza nenhuma a respeito de como acontecera a morte, mas os relatos de pessoas que acompanharam o cortejo deixam perceber que se pensava coletivamente de uma forma assemelhada à seguinte:

[...] hoje se diz que ele foi morto em um assalto. Mas lá na praça ia dar risada o povo se alguém conta uma história dessas. Aquele homem grande daquele jeito, que só andava armado e com um monte de segurança, morrer assaltado... nem dá pra pensar. Você perguntou o que que eu sentia. Sentia tristeza pela morte de um parente, porque pra mim ele era que nem um da família. Desde muito tempo ele ajudava a gente lá de casa dando colégio pras criança estudar (...) levava doente pro hospital qualquer hora da madrugada, dava material pra obra (...) porque eu e meus filhos é que fizemos obra pra morar, meu marido morreu há muito tempo e sobrou pra nós... ele nem era político ainda e já ajudava (...) era um pai pros meus filhos (...) gostava de gente pobre porque ele também era trabalhador e pobre (...) eu tinha que ficar naquele frio esperando o corpo que nunca chegava, era que nem uma obrigação pra mim (...) nunca vai existir um outro político aqui igual

\footnotetext{
${ }^{5}$ A versão apresentada aqui para a morte de Joca foi baseada dos seguintes periódicos: Jornal de Hoje, 21 jun. 1995, pp. 3-7; O Dia, 21 jun. 1995, pp. 3-5 e Hora H, 21 jun. 1995, pp. 2-5.

${ }^{6} \mathrm{O}$ primeiro prefeito do município de Japeri, Carlos Moraes Costa, costumava chamar Joca de o "governador da Baixada" talvez devido ao fato de o prefeito de Belford Roxo ser o presidente da "Associação de Municípios da Baixada Fluminense e Adjacências”. Jornal de Hoje, 06 nov. 1993, p. 2.

${ }^{7}$ Jornal de Hoje, 23 jun. 1993.
} 
ele. Têm uns aí que cisma de dar pão e sopa pra gente mas é falsidade. Passa a eleição eles desaparece (...) ele não era só político era um homem que ajudava se tinha ou não eleição. Tava presente o ano todo. ${ }^{8}$

Cem mil pessoas não ocupariam uma praça na madrugada de quinta para sextafeira para esperar um cadáver não querido, é lógico. Existem aspectos dessa espera, entretanto, que a diferenciam de um simples desejo coletivo de homenagear um político popular morto.

Escapa do depoimento a nítida impressão de que a entrevistada considera o seu deslocamento como uma obrigação. Joca é, para dona Maria, um "membro da família", ou, até mais que isso, pois ela afirmará em outra parte da entrevista que, quando "gente da minha mesma família me abandonou, ele me ajudou”. O líder morto, nesse momento de velório, está mais do que durante toda a sua trajetória política unido ao "seu povo", que não é para aí conduzido, mas, em um típico comportamento de massa, conduz-se com a finalidade única de reverenciar alguém considerado um herói. O comportamento popular legitima o entendimento de Joca como uma espécie de salvador.

Representantes da antiga elite política local sentiam-se também desamparados ante a morte do primeiro prefeito de Belford Roxo, como comprova o editorial em tom profético do Correio da Lavoura do dia 23 de junho de 1995 que concluía:

[...] correr Belford Roxo o perigo de retornar ao período negro da sua história, quando bandidos conhecidos notabilizaram-se por infernizar a vida de sua população que experimentou por um prazo muito curto a paz garantida por um dos maiores líderes políticos dessas plagas. ${ }^{9}$

A ideia de estabilidade do governo Joca lembrada pelo editor de $O$ Correio $d a$ Lavoura talvez se deva a lembranças fortes como a evocada por um entrevistado que justificava sua admiração ao prefeito morto relembrando um acontecimento inusitado em que ele fora a única pessoa a conseguir fazer com que alguns traficantes permitissem que os bombeiros recolhessem o cadáver de um desafeto deles, morto já havia quatro dias, e que, por conta disso, contaminava com sua podridão toda a vizinhança. Segundo o entrevistado, morador de um bairro popular próximo ao centro do município, o prefeito, ao saber por parte de moradores do acontecido, abandonou seu gabinete e subiu o Morro da Galinha junto com o carro dos bombeiros. Chegando lá, Joca não se contentou em assistir ao recolhimento do cadáver: procurando quem havia impedido a retirada

\footnotetext{
${ }^{8}$ GUIMARÃES, Maria Teixeira. Entrevista Concedida em 02 set. 1995.

${ }^{9}$ Correio da Lavoura, 23 jun.1995, p. 01.
} 
anterior do corpo, fez com que o próprio traficante levasse o defunto "já podre" até a viatura dos bombeiros. ${ }^{10}$

Por mais inverossímil que essa história seja (e não é possível apurar a sua veracidade), ela ilustra o modo como Joca era visualizado pela população: para além de ser um político, ele era considerado como o proprietário de soluções para problemas que, apesar de poderem ser considerados como simples, perpetuavam-se ganhando o status de insolúveis.

A espera na madrugada fria é parte de um processo de mitificação, no entanto, é perceptível que tal espera, longe de simbolizar a construção de um exemplo através das aparas da imagem de um político tradicional, equivale a uma homenagem a quem melhor conseguiu aproximar-se do povo e de suas práticas de resolução de problemas. O papel do mito aqui sofre uma espécie de inversão: apesar de continuar a reboque de uma construção, não existiu espaço para nenhum elemento da elite política regional construir a imagem ideal de Joca. Ao contrário disso, o retrato prevalecente foi o construído pela própria população, tendendo o resultado a espelhar soluções pouco convencionais para problemas tornados crônicos ante a pequena presença de ações estatais na região da Baixada.

Amanheceu o dia 21 de junho de 1995. O centro comercial de Belford Roxo logo se tornou pequeno demais para comportar a multidão que teimava em não se organizar a fim de ver o corpo de Joca. A fila que se estendeu por mais de dois quilômetros deu lugar rapidamente a uma procissão que teve como destino final o cemitério da Solidão, tendo inicialmente percorrido todo o pequeno centro da cidade, indo até o ostentoso pórtico de entrada da cidade mandado construir um ano antes pelo prefeito agora morto.

A multidão para sob o pórtico.

Enfatiza um jornal local ser possível, durante essa parada, ouvirem-se lamentos traduzidos em frases curtas como: "perdemos nosso pai!" e "Belford Roxo nunca mais será a mesma”.

Após essa parada a procissão seguiu seu destino - o túmulo onde futuramente seria gravada a frase "Serei sempre Joca" com um coração construído com lâmpadas fluorescentes.

\footnotetext{
${ }^{10}$ NOVAES, Mário Geraldo. Entrevista Concedida em 02 set.1995
} 
Durante todo o cortejo fúnebre e até no cemitério, percebe-se uma disputa realizada por políticos locais que desejavam homenagear o prefeito através de discursos. As lamentações populares, entretanto, sufocam tais tentativas de homenagem. Seguindo as descrições expostas pelos periódicos, percebe-se que ocorre nessa condução do cadáver uma apropriação popular da figura de Joca. Sobra pouquíssimo espaço para os correligionários do prefeito. A massa formada em torno da morte de Joca determina a impossibilidade de pensar que essa morte pudesse funcionar como uma oportunidade para que um grupo de amigos iniciasse isoladamente um processo de mitificação política. Nos dias seguintes a essa procissão e enterro, o túmulo de $n^{\circ} 2409$ do Cemitério da Solidão passou a receber uma grande quantidade de visitantes, alguns deles deixando alguns pequenos bilhetes como os de algumas alunas de um colégio particular do município:

"Joca, desejamos que você esteja em paz. Pelo sorriso que você tinha e pelo prefeito que você era, um beijo dos alunos do Centro de Educação Moderna."

Ou esses bilhetes deixados por populares que não se identificaram:

"Tio Joca, ilumine os nossos dirigentes de onde você estiver."

"Continue ajudando Belford Roxo a ser a cidade do amor."

"Nunca mais teremos um prefeito como você, que foi o único a se preocupar com pobre."

Descartada a possibilidade de imaginar que existiu uma condução para o processo de mitificação política de Joca, resta-nos pensar que ele notabilizou-se por refletir anseios populares e somente é possível pensar nele como alguém que corporificou inúmeros anseios dessa população fundida a ele. A identificação é aí direta, sendo difícil pensar em Joca como alguém destacado das classes subalternas habitantes da Baixada. Ele é, tal como demonstrado em seguida, o resultado extremado de uma maneira popular de resolver problemas políticos.

\section{Uma mitificação fluida}

Dia 20 de junho de 1999. Feriado municipal em Belford Roxo em lembrança da morte do primeiro prefeito. O túmulo de Joca não contrastaria em muito com aquele mesmo túmulo no dia 21 de junho de 1996 se não fosse por um detalhe: segundo os funcionários do cemitério a rotina nesse dia em nada lembrava uma data especial. Logo cedo um carro da Prefeitura entrou no cemitério e dois ramalhetes de flores foram con- 
duzidos ao túmulo de Joca. Menos de dez pessoas visitaram o túmulo nesse dia - quarto aniversário da morte de Joca - nem sequer uma nota foi publicada na imprensa local. Estranho isso ocorrer com o prefeito que, mesmo depois de morto, conseguiu reunir em torno de si aliados e adversários políticos, conduzindo ao executivo municipal sua esposa e ao legislativo municipal e estadual candidatos que pautaram suas campanhas enfatizando uma estreita ligação com as práticas do ex-prefeito. Teria o mito político se desfeito? As condições que permitiram a Joca exercer um poder tão invejado pelos demais prefeitos da região dissolveram-se?

Em lugar de decepcionar, o silêncio demonstrado pela população poucos anos após a passagem de Joca pela Prefeitura desse município revela-nos algo fundamental para entender a peculiaridade das soluções encontradas por essa população e, ao mesmo tempo, o recurso a indivíduos que assessoram essa mesma população no encontro dos caminhos para a resolução do que chamo de problemas práticos.

A mitificação política de Joca é fluida porque na realidade todo o seu carisma embasava-se muito menos em seus atos espetaculares e muito mais na percepção popular de que Joca era parte das classes subalternas e de que suas soluções somente diferiam em grandeza daquelas tradicionalmente encontradas pela população das periferias dali.

Não era possível, portanto, que o processo de mitificação política de Joca se restringisse a objetos concretos como um túmulo, um livro de memórias, uma estátua, o nome de uma avenida, de um hospital, da estação de trens urbanos ou na existência de um feriado municipal em sua homenagem.

Muito mais próximo que todos os objetos e datas que possam lembrar Joca está a convivência diária com problemas para os quais o prefeito significava, em primeiro lugar, uma solução. Solução que, mesmo parcialmente, já era proporcionada pela rede de resolução de problemas práticos. ${ }^{11}$ Considerar Joca como o homem que age em confor-

\footnotetext{
${ }^{11}$ Rede de resolução de problemas práticos é uma noção pensada por mim ainda no momento em que escrevia a monografia de final de graduação em História. Pretendia eu naquela ocasião englobar a gama variada de resolução de problemas levados adiante pela população dos bairros periféricos da Baixada Fluminense em uma teia invisível que designei dessa forma. Assim, tanto o ato simples de manter a frente de sua própria casa limpa até o assassinato de bandidos por bandos de justiceiros, que eu identifiquei como constituídos por moradores dos próprios bairros proletários dali, foram colocados dentro de um mesmo cenário e categorizados como elementos componentes dessa rede marcada fundamentalmente pelo fato de serem constituintes dela quaisquer ações populares destinadas à amenização das agruras componentes da vida proletária na região da Baixada Fluminense. Vida marcada sobretudo por desenvolver-se bastante distante de qualquer presença do Estado. A noção nasceu em um momento em que eu percebia ser necessário encontrar alguma maneira de dar ordem ao que sabia ser um caos epistemológico. Não era muito difícil juntar casos flagrantes de ausência do poder público na vida de "comunidades" da Baixada e
} 
midade com essa rede auxilia no entendimento dos motivos existentes para o "esquecimento" popular da figura de Joca.

Ele assemelhou-se a um símbolo e, mesmo morto esse símbolo, o que o gerou continua atuando e dirigindo a sua atenção para outros agentes espetaculares ou mesmo para a muda ação de construção e manutenção de equipamentos urbanos tão comum na Baixada Fluminense.

Não se deve em momento algum entender Joca como superior a todo o conjunto de soluções encontradas pela população periférica. $\mathrm{O}$ fato de ser transformado em mito revela unicamente uma profunda identidade entre Joca e a população "submetida" a ele. Identidade forte o suficiente para dispensar a necessidade da manutenção do mito que parecerá ser enterrado em um tempo recorde.

É inegável que a reação popular à morte de Joca e os gestos populares relacionados aos seus funerais dificilmente poderiam deixar de dar a ele os louros da vitória de uma santificação. Por si só sua morte retira da obscuridade qualquer dúvida de ser ele o herói salvador destinado a conduzir a população de Belford Roxo até um porto seguro distante o bastante do caos a que pode ser comparada a Baixada Fluminense.

Joca é o habitante de um mundo em crise e assume um papel relevante na indicação de soluções para os inúmeros problemas que atingem a população periférica fundida a sua imagem.

A Baixada Fluminense é um mundo em constante crise, uma vez que para ali se destinaram indivíduos oriundos do interior do Brasil, socialmente invisíveis e quase integralmente esquecidos pelas diversas esferas do poder público: cidadãos-só, em suma.

Estabeleceu-se na Baixada Fluminense uma estrutura de carências capaz de alimentar as condições adversas já existentes desde os momentos iniciais da ocupação.

menos difícil era também perceber que moradores de bairros periféricos construíam caminhos próprios para a resolução de problemas imediatos sempre crescentes devido ao próprio desenvolvimento demográfico da região e também pela diminuição relativa da original insignificante, presença estatal. Assim, na base de minha rede figurava exatamente a ausência pública existente já no processo descuidado de ocupação da antiga terra agrícola, e geradora do que chamei de resolução de problemas práticos. Na medida em que o Estado não se materializava, pareceu ser necessário ao conjunto de moradores dos bairros periféricos organizarem-se de maneiras diversas a fim de substituir de forma minimamente eficiente o Estado. Por isso compõem a rede tanto coisas muito simples e presentes em tantas periferias como construir um precário serviço de esgotamento sanitário, que se inicia quase sempre com a abertura de uma vala negra e com a manutenção das frentes dos lotes por onde passam as valas, limpos, até ao processo comunitário, através das fofocas, de escolha de quais serão as vítimas dos justiçamentos levados adiante pelos grupos de "matadores de bairro", diferentes dos grupos de exterminadores formados quase sempre por policiais e bombeiros militares (Cf. Monteiro, 1996). 
Joca surgiu então exatamente no momento em que essa estrutura de carências patrocinada pelo Estado explodia sob a forma das emancipações distritais. No final da década de 1980, torna-se insuportável para a população da região da Baixada Fluminense conviver com a inacessibilidade do poder público municipal representado pela Prefeitura do grande município de Nova Iguaçu e é de fundamental importância, nesse momento político decisivo de retorno da democracia e de elaboração de uma nova Constituição federal, em cada distrito do município de Nova Iguaçu fazer subir ao poder um representante distrital, uma vez que os antigos líderes populares distritais transformados em vereadores e estabelecidos como pontes entre suas regiões e a Prefeitura iguaçuana não dão conta de dar visibilidade aos habitantes de cada um desses locais. Nesse momento decisivo surge Joca que passaria despercebido caso não fosse o portador de soluções eficientes dirigidas para o estabelecimento de organismos públicos capazes de substituir a rede de resolução de problemas práticos.

Não seria possível pensar Joca como um salvador político no estilo de um Tiradentes ou um Marechal Floriano Peixoto na medida em que sua imagem não se prestou a uma construção intencional. Ao contrário da missão de um salvador construído, Joca emoldurou-se a uma tela já construída pela população da Baixada Fluminense enquanto esta ampliava a autoconstrução para o espaço público. Ele destaca-se exatamente por assemelhar-se ao grosso dos habitantes dos bairros periféricos da Baixada Fluminense. Nesse aspecto não é um herói da exceção, mas sim o elemento mais capacitado a ocupar o poder público, exatamente por destacar-se dos demais políticos representantes de uma elite política regional.

Nada difícil é concluir, portanto, que a mitificação política de Joca não atende à necessidade de um determinado grupo de eleger um símbolo como elemento sintetizador dos anseios da preservação de um mundo político. Joca é, ao contrário, o aprovado e prático autor de mudanças profundas (destrutivas/construtivas) em um mundo caótico. Mas vejamos um pouco de sua vida.

\section{3. “(...) minha ideologia política é o povo"}

Acompanhar a transformação pessoal sofrida por Joca no seu caminho até a Prefeitura de Belford Roxo permitirá que se pense melhor na sujeição deste a todo um conjunto de antigas práticas criadas pela própria população periférica da região da Baixada Fluminense. 
A mídia não era algo muito querido por Joca. Muito provavelmente por isso, durante sua pequena vida pública, poucas foram as entrevistas concedidas por ele. É fácil concluir as razões dessa ojeriza à imprensa: ele somente chorara duas vezes depois de adulto e uma dessas vezes devera-se aos jornalistas. ${ }^{12}$ Manter distância da imprensa era então uma boa estratégia, segundo o prefeito para "sofrer menos". Na realidade tal estratégia não funcionava muito bem porque os atos de Joca primavam pelo espetáculo e isso determinava que a imprensa local quase que diariamente se ocupasse da descrição desses espetáculos. Aliás, a atitude hostil dessa imprensa existiu até o momento em que Joca passou a ser considerado uma figura política marcada para a liderança de seu município: logo após a eleição de 1992, um articulista do Jornal de Hoje cobra de Joca uma atitude em relação ao editorial "Eleições manchadas de sangue"13 publicado no Jornal do Brasil em que, segundo o articulista, a população belford-roxense fora atacada quando o Jornal do Brasil considerou, segundo o articulista do Jornal de Hoje, a escolha de um "matador" para o Executivo de um município fluminense como o exemplo de quanto essa mesma população era "alienada" e "ignorante". 14

Os processos judiciais abertos contra Joca não pesavam mais para a imprensa da Baixada, para a qual ele era agora "o prefeito de um dos mais ricos municípios dessa região" e não mais o "participante de um grupo de extermínio". Apesar de sua raridade, as entrevistas concedidas por ele constituem-se nas únicas fontes capazes de nos informar sobre a sua origem e a maneira como ele destacou-se dentre os demais migrantes fluminenses até tornar-se o prefeito do município onde viveu por quarenta anos antes de tornar-se prefeito.

Joca, tal como grande parte da população de Belford Roxo, não era originário da região da Baixada. Ele viera bem cedo do interior do Estado do Rio de Janeiro e, segundo seu próprio relato, começou a trabalhar ainda criança, pois pertencia a uma família muito grande e pobre (treze irmãos, filhos de uma merendeira e de um operário da Rede Ferroviária Federal). Vendeu bala nos trens, foi ajudante-de-obras, pedreiro, cobrador e motorista de ônibus, lutador de luta livre e carroceiro antes de transformar-se em um bem-sucedido empresário do setor de transportes e construções. ${ }^{15}$

\footnotetext{
12 Jornal de Hoje, 18 out. 1993, p. 05.

${ }^{13}$ Jornal do Brasil, 19 out. 1992, p. 10. O articulista do Jornal de Hoje equivocou-se. Na verdade o editorial intitulava-se "Voto de Sangue".

${ }^{14}$ Jornal de Hoje, 22 out. 1992, p. 04.

15 Jornal de Hoje, 21 nov. 1993, p. 05.
} 
Sobressai, da leitura de entrevistas, o fato de Joca deixar claro não ser importante para ele relembrar um passado comum à grande parte dos migrantes belford-roxenses, nem mesmo que a sua intenção possa ser vangloriar-se pelo fato de destacar-se em relação à grande massa socialmente submetida da qual emergiu. A parte da sua vida que merece destaque, segundo ele, é aquela que se inicia quando ele resolve, “... não pensando em exercer nenhum cargo, fazer o trabalho social”. E tal prática inicia-se, segundo o prefeito, de uma maneira bastante simples: ele constatou que... "Ambulância sempre foi uma coisa muito difícil por aqui e achei que essa era a melhor maneira de ajudar. Hoje mantenho catorze unidades, uma delas com UTI". ${ }^{16}$

Muito embora Joca não se preocupe em detalhar como foi o início do seu serviço social, alguns entrevistados informaram que tudo começou com um carro velho (um Volkswagen tipo Brasília) que recebeu uma pintura com o apelido do futuro prefeito, tendo a figura de um coração substituindo graficamente a letra "O" do apelido Joca, e passando a partir daí a servir como ambulância:

[...] como não tinha nada... e ele nas piores horas, de madrugada, servia o povo levando pra hospital do Rio. A gente batia na casa dele qualquer hora quando precisava em uma emergência e ele nunca se negava a atender... acho que ele começou a fazer isso no início sem tanto interesse em ser alguma coisa. Aqui no bairro só tem pobre e ele sendo mais rico passou a ter pena de nós eu acho... depois é que pode ser que ele já não fizesse tanto por pena mas também por interesse de se eleger. ${ }^{17}$

Ainda como morador do bairro de Heliópolis, ${ }^{18}$ na periferia de Belford Roxo, Joca passou da ambulância improvisada à construção de um "serviço social" e, durante a década de 1980, quando começava a ganhar força a antiga ideia de emancipar-se o distrito de Belford Roxo, Joca, apesar de não ser ainda candidato passou a distribuir cestas básicas, sopa, materiais de construção e proteção a moradores ameaçados por bandidos. Sua fama de benfeitor e de homem valente atraía políticos e fez nascer nesse migrante “desinteressado" a percepção de ser possível para ele candidatar-se à Câmara de Vereadores de Nova Iguaçu.

\footnotetext{
${ }^{16}$ Jornal de Hoje, 21 nov. 1993, p. 05.

17 MONTEIRO, Florêncio Marcos. Entrevista Concedida em 23 nov. 1995.

${ }^{18}$ Oficialmente Joca nunca deixou de ser morador de Heliópolis, porém não tinha somente uma casa. Era famoso em Belford Roxo por ser amante de pelo menos cinco mulheres. Mantinha cada uma delas em uma casa sua e visitava suas amantes regularmente; sua esposa, porém, continuava morando em Heliópolis.
} 
Da velha Brasília para os muros, o nome Joca - agora acompanhado do slogan "O homem que ama Belford Roxo" - revela logo na primeira e única eleição para vereador possuir uma farta energia eleitoral.

Em um resumo rápido, a trajetória eleitoral de Joca pode ser apresentada da seguinte maneira: candidatou-se à Câmara de Vereadores de Nova Iguaçu em 1988 e elegeu-se nesse pleito com o maior número de votos válidos (mais de cinco mil votos). Em 1992 elegeu-se prefeito de Belford Roxo com 69,8\% do total de votos, dispensando o segundo turno. ${ }^{19}$

Muito embora, ao relembrar o seu primeiro cargo eletivo, o prefeito tenha admitido não ter sido um vereador assíduo e combatente - um acidente grave, segundo ele, obrigou-o a afastar-se da Câmara Municipal por um ano e quatro meses ${ }^{20}$-, as muletas, que diz ter usado durante onze meses, não o impediram de demonstrar sua preocupação para com "o seu povo". Mostra essa preocupação o fato de, mesmo enquanto não podia frequentar a Câmara Municipal, ter continuado "atendendo aos pedidos da população" em seu serviço social.

Como saldo da sua primeira aventura eleitoral ostentou o saneamento de 149 ruas e a construção de 9 postos médicos. Revelando-se um conhecedor profundo das principais necessidades da população que o elegeu, o vereador Joca utilizou o cargo para estender a sua influência junto aos moradores de seu distrito. Fazendo a sua primeira migração partidária, troca o Partido do Movimento Democrático Brasileiro (PMDB) pelo Partido Democrático Trabalhista (PDT), estreitando sua aproximação com o prefeito de Nova Iguaçu, Aluisio Gama. Essa aproximação permitiu a Joca demonstrar ao "seu povo" que, além de ser um vereador ativo, mantinha relações com elementos que poderiam favorecer a futura emancipação de Belford Roxo e a imediata realização de obras que pudessem diminuir as agruras da população do distrito.

É preciso lembrar que, naquele momento, Aluisio Gama, prefeito iguaçuano entre 1988 e 1992, era favorável à emancipação de Belford Roxo e mantinha com Joca uma relação amistosa, sempre atendendo às indicações de obras propostas pelo vereador - fato que servia para que Joca se destacasse dos demais vereadores que tinham como origem Belford Roxo. Ao mesmo tempo, era estratégico para o prefeito iguaçuano man-

19 Jornal de Hoje, 21 nov. 1993, p. 5, 20 mar. 1992, p. 03. Se levarmos em consideração somente o total de votos válidos, Joca se elegeu com mais de $80 \%$ da preferência popular.

${ }^{20}$ Apresentando sucessivos pedidos de afastamento, não encaminhando nenhum projeto e não se pronunciando sequer uma vez, na realidade o prefeito enquanto foi vereador de Nova Iguaçu caracterizou-se pela nulidade da sua representação. Atas da Câmara Municipal de Nova Iguaçu, 1990-1993. 
ter-se presente no distrito de Belford Roxo e vincular sua imagem a alguém tão carismático, uma vez que ali existia uma quantidade grande de eleitores que poderiam auxiliá-lo na continuidade de sua carreira política. Provavelmente visando o seu futuro, Aluisio Gama reorganizou todo o centro do distrito de Belford Roxo, mesmo após a decisão de que o distrito deixaria de pertencer à Nova Iguaçu, fato que auxiliou Joca em sua escalada rumo à primeira prefeitura belfordroxense, já que as obras realizadas na administração Aluisio Gama foram indicações do vereador Joca.

Apesar de ter sua importância aumentada, as matérias de periódicos locais sobre o vereador Joca revelam um homem tão acanhado politicamente a ponto de desconhecer sua própria influência, fato que o levou a aceitar uma composição política em que seria lançado vice-prefeito caso um mandato-tampão ocorresse em $1990 .{ }^{21}$ Ou seja, apesar de assediado por candidatos de diversos partidos, Joca ainda reconhecia a liderança política tradicional existente no novo município.

A ação de suas ambulâncias, dos materiais de construção que distribuía, das cestas básicas, das sopas e a aliança com o prefeito de Nova Iguaçu acabaram convencendo Joca de que era possível voos independentes e solitários. Voo alçado em 1991, quando se lançou candidato à Prefeitura belford-roxense desvinculado da elite política tradicional do antigo distrito.

Necessário faz-se pensar no fenômeno Joca delimitando as fronteiras da sua figura, definindo-o como diverso dos habitantes de seu métier político. No sucinto relato da transformação do homem comum Joca em prefeito de um município importante da região da Baixada Fluminense, destacam-se três tempos distintos: em um primeiro, Joca é alguém que, confundido com todos os outros habitantes de Belford Roxo, poderia ser definido como aquele que percebe de uma maneira diversa sua realidade e a de seus circundantes desenvolvendo o que ele mesmo chamou de "sensibilidade social". 22

Em um momento intermediário, em que talvez graças a esta "sensibilidade" parece perceber não ser a informalidade algo muito confortável, nosso personagem imaginará que pode fazer muito mais pelos "seus" transformando-se em um representante oficial dos belford-roxenses que são seus "vizinhos".

Finalmente é possível encontrar nosso homem - a princípio timidamente - tomando consciência de que ele é bem mais que um simples representante popular, ele é,

\footnotetext{
${ }^{21}$ Jornal de Hoje, 13 abr. 1992, p. 03.

${ }^{22}$ Jornal de Hoje, 11 out. 1992, p. 05.
} 
sim, o eleito: aquele que, ao contrário de vários outros políticos regionais, ${ }^{23}$ pode alçar voo solitário, lançar-se contra toda a tradicional classe política local que, aliás, golpeouo de início, para depois submeter-se acelerando sua escalada para o centro das atenções políticas locais.

Se a elite de uma determinada região é representada por aquelas pessoas que detêm a maior parte dos poderes, por serem mais organizadas e por possuírem interesses comuns, situação que os transforma em solidários pelo menos na manutenção das regras do jogo (Bobbio, 1986:385-391), pode-se afirmar que em Belford Roxo existia uma elite bastante aproximada em seus interesses.

Algumas famílias tradicionais haviam possuído propriedades importantes no "Velho Brejo", porém pode-se pensar que constituíam a elite local tradicional de Belford Roxo elementos que se destacaram dentro do antigo distrito como comerciantes, profissionais liberais e industriais, a partir principalmente do loteamento dessa região fato que transformou Belford Roxo em um local excelente para o desenvolvimento de atividades econômicas relacionadas ao comércio e à indústria.

A elite regional belford-roxense não diferia de forma acentuada em 1991 daquela própria de todos os municípios da Baixada: pessoas enriquecidas à custa de atividades recentemente praticadas nessa região e que haviam substituído os citricultores da década de 1950, de tal forma que, se tivéssemos de pensar em uma época para o surgimento da elite local que se opunha a Joca, deveríamos pensar não em um passado muito remoto, mas sim na época de transição econômica, quando os loteamentos surgiram salvando parte dos citricultores, transformados forçadamente em loteadores, e dando à região da Baixada uma função dormitório. Tal função permitiu o acúmulo de capitais por parte de alguns elementos que, para melhor garantir as suas conquistas, terminaram ocupando os executivos e legislativos municipais da região.

Em Belford Roxo, Ediraldo Gomes, Waldir Vilela, Ricardo Gaspar, José Haddad e Osvaldo Lima transformaram-se em representantes políticos da elite regional. Há vários anos lutando pela "supremacia política" (Peixoto, 1960:54) de Belford Roxo, esses

\footnotetext{
${ }^{23}$ Em um artigo publicado em 30 de novembro de 1991, um articulista do Jornal de Hoje admira-se com o fato de representantes de tradicionais famílias se acotovelarem disputando a possibilidade de Joca servir como candidato a vice em chapas sempre encabeçadas por essas lideranças. $\mathrm{O}$ articulista lê nessas disputas a evidência maior de que "a política em Belford Roxo gira em torno de Joca", vereador por Nova Iguaçu eleito com mais de cinco mil votos, todos eles de belford-roxenses, e que tinha "a cara e a simplicidade política do povo respondendo sempre com franqueza e sobremaneira preocupado com a eliminação das vergonhas que assolam aquele ex-distrito iguaçuano com toda a certeza o mais abandonado de todos os distritos de Nova Iguaçu”. Jornal de Hoje, 30 nov. 1991, p. 02.
} 
políticos conformavam-se com um certo padrão de comportamento, caracterizado pela indiferença à população mais pobre, somente procurada em épocas de campanha eleitoral.

A sobrevivência desses políticos dentro dos distritos iguaçuanos habitados principalmente por elementos populares não chega a ser uma façanha se considerarmos que a população belford-roxense não se preocupava acentuadamente com a competência de seus governantes e representantes. Prefeitos e vereadores eram elementos estranhos, distantes, sendo "natural" para os belford-roxenses serem esquecidos pelos políticos vistos sempre como "espertalhões". O momento da eleição sobressaía como o único importante da relação na medida em que se poderia negociar o voto, alcançando-se assim alguns benefícios pessoais ou coletivos:

\begin{abstract}
Antes da emancipação e do governo do Joca, os político espertalhão comandava aqui... comandava não é verdade: eles era eleito. Só que como a gente era obrigado a votar, trocava a promessa de votar em qualquer um por alguma coisa pra gente ou para o bairro. Era natural a gente só ser lembrado na política [eleição] depois tudo mudou muito. A gente passou a ser ouvido todo o tempo tanto pelo prefeito como pelos vereadores. ${ }^{24}$
\end{abstract}

A diferença entre Joca e outros políticos é simples: ele conhecia a vida dura e se preocupava em dar alguma melhoria pro povo. Não pensava só nele só. Antes era tão diferente. Prometiam. Ninguém acreditava. Conseguia às vezes alguma coisa e depois nem se via o candidato. Depois do Joca não. A gente é valorizado e via o prefeito e os vereadores sempre. ${ }^{25}$

Pode-se pensar que, em toda a região da Baixada Fluminense, a indiferença popular aos políticos representantes das elites regionais correspondia a uma regra, o que pode ser exemplificado pelos atos de "protesto" político praticados por alguns eleitores nas eleições municipais de 1992 quando a soma de votos nulos e abstenções em Nova Iguaçu chegou a 33\% do total, chamando mais a atenção cédulas que continham restos de fezes e um número excessivo de votos em times de futebol, jogadores e em personagens de novelas. ${ }^{26}$

Para além da percepção da oposição entre os políticos tradicionais e Joca, é possível pensar, a partir da fala dos entrevistados, que a política ordinariamente praticada na Baixada passou a significar algo incômodo. Em comparação com o político tradicional, o líder marginal carismático era um elemento inovador. A sua aceitação por parte

\footnotetext{
24 PIRES, Marcelino de Freitas. Entrevista Concedida em 12 abr. 1997.

25 FERNANDES, Paulo. Entrevista Concedida em 02 set. 1998.

${ }^{26}$ Jornal de Hoje, 21 nov. 1992, p. 06.
} 
da população dali exigia uma adaptação dos políticos tradicionais, algo que não ocorreu, entretanto. Em lugar da adaptação, a elite política local sujeitou-se aos novos líderes marginais, destacando-se dentre esses Joca.

Todas as distinções políticas de Joca somente podem ser visualizadas se pensarmos na ação desse líder junto a essa massa socialmente subalterna da periferia da Região Metropolitana do Rio de Janeiro ou, dizendo-se de uma maneira diferente, deve-se sempre pensar em Joca como um personagem produzido e conduzido em função da vontade popular. De início ele não é em nada diferente de seus vizinhos. Incomodado exatamente pelos mesmos problemas, Joca inicia o seu descolamento ao tornar-se uma voz ativa, ou melhor, uma ação ativa e que extrapola a autorresolução de problemas em que ele estava diretamente envolvido: Joca deixa de ser o sujeito que conversa com dois de seus colegas de rua e resolve, por exemplo, manilhar uma vala negra que passa em frente de sua casa: ele "preocupa-se" em "fazer o serviço social", ${ }^{27}$ o que equivale a uma maneira mais efetiva de substituir o Estado.

Pode-se pensar em Joca com toda a justeza como o representante típico da maneira original do habitante das periferias da Baixada resolver o seu problema de diálogo com o poder público. Tanto é assim que o vereador Joca não deixou na Câmara Municipal de Nova Iguaçu nenhuma marca de sua passagem. Todas as suas preocupações nesse período iam ao encontro de otimizar sua ação como agente executivo - o que lhe garantiu chegar à Prefeitura belford-roxense sendo o proprietário de um serviço social que contava com "catorze unidades [ambulâncias], uma delas com UTI", ${ }^{28}$ uma ampla rede de distribuição de cestas básicas, máquinas que serviam na abertura e limpeza de valas negras e na reabertura de ruas tomadas pelo mato, com um grupo de funcionários que atendiam pessoas com problemas como ausência de vagas em colégios ou falta de emprego, dois postos de saúde e duas clínicas. ${ }^{29}$ Para além disso, Joca - bem distante da imprensa - orgulhava-se por conseguir “intimidar bandidos”. Isso fazia inúmeras pessoas procurarem-no diariamente na Prefeitura a fim de conseguir proteção dada por grupos de extermínio controlados por "amigos do Joca". ${ }^{30}$ Esta última característica do prefeito acabaria fazendo com que as pessoas atribuíssem a ele as - sempre bem-vindas - mortes

\footnotetext{
${ }^{27}$ Jornal de Hoje, 21 nov. 1993, p. 05.

${ }^{28}$ Jornal de Hoje, 21 nov. 1993, p. 05.

${ }^{29}$ Jornal de Hoje, 01 jul. 1992, p. 07.

${ }^{30}$ Jornal de Hoje, 21 jul. 1993, p. 05.
} 
de bandidos, alimentando a antiga acusação de ser ele o chefe de um grupo de extermínio. $^{31}$

Era comum durante o período de ascensão política de Joca compararem-no a Tenório Cavalcanti. Alguns jornalistas locais chegavam a pensar em Joca como o "sucessor legítimo" 32 daquele político que viveu em um tempo conturbado em que a região da Baixada sepultava a sua antiga tradição rural e transformava-se muito rapidamente em uma das regiões onde a disputa pela propriedade das terras gerava enormes conflitos que jogavam grandes e decadentes proprietários contra miseráveis migrantes nordestinos que buscavam na Baixada a chance de obter casa própria e, ao mesmo tempo, manterem-se distantes das favelas cariocas.

A trajetória política de Tenório é bem conhecida e sobressai de sua biografia o fato de esse político - que chegou à Baixada durante a década de 1920 fugindo dos assassinos de seu pai - estar inserido em uma rede clientelística que conseguiu atingi-lo no distante Estado de Alagoas. Quando fugiu de seu estado, Tenório foi trabalhar na fazenda de um parente de sua mãe que devia favores ao seu falecido pai antes deste último empobrecer. Tenório agiu durante todo o tempo dentro de uma intrincada rede clientelística onde se casou com a filha de um antigo prefeito de Nova Iguaçu ligado ao parente de sua mãe que o recebeu primeiramente. Jamais Tenório distanciou-se desse tipo de relação baseada no comprometimento entre semelhantes. A população da Baixada entra nesse jogo como um desigual, surgindo para Tenório como uma forma eficiente de garantir seu poder através da ocupação da região por gente de sua confiança, principalmente "cabras" (Cavalcanti, 1996:50) valentes que o servissem nos momentos de confronto com os antigos proprietários.

É possível encarar Tenório, dessa forma, como o sujeito que se distingue dos demais na medida em que, partindo de um papel subalterno dentro de uma rede clientelística, transforma-se no líder de uma facção que se caracterizará pelo uso da violência como maneira de galgar posições antes ocupadas por adversários.

O uso da violência que inicialmente serviu para alcançar posições, posteriormente garantiu - como que por acidente - a proteção da população migrante que não cessou de chegar em Duque de Caxias até a década de 1980. Tenório Cavalcanti é provavelmente o primeiro dos políticos assistencialistas dessa região, mas somente o assistencialismo não é suficiente para transformá-lo em líder popular se considerarmos que a popu-

\footnotetext{
31 Jornal de Hoje, 11 out. 1992, p. 05.

${ }^{32}$ Correio de Maxambomba, 11 dez. 1991, p. 04.
} 
lação da Baixada era para Tenório Cavalcanti unicamente algo assemelhado àquele "parceiro fantasma" celebrizado por autores que acreditavam na existência do populismo (Weffort, 1980), estando, entretanto, o político Tenório Cavalcanti e a massa recentemente mobilizada e sujeita a ele distanciadíssimos pela prática de uma série de subterfúgios necessários ao ofuscamento popular e ao impedimento de uma efetiva participação no jogo político.

Ao contrário de Tenório Cavalcanti, entre Joca e a população belford-roxense não há uma distância sensível. Nesse caso comparações que não cessem na proximidade geográfica tendem a criar anacronismos, e mesmo se pensarmos no assistencialismo de Joca, existem distinções claras, pois se essa prática é possibilitada pelo cenário de desolação social que, perpetuamente, é a Baixada Fluminense, as intenções são diversas: Joca continuaria existindo sem o seu assistencialismo. Ele não se elegeu "enganando" seus "vizinhos". Existiu toda uma história anterior que permitiu ao morador de Belford Roxo identificar-se com Joca e que fez com que mulheres e homens dali lessem os métodos de Joca como não diferentes, senão em intensidade, dos atos que os próprios moradores ordinários praticaram durante toda a sua vida em Belford Roxo.

Essa identificação entre o líder e a massa foi tão intensa que Joca não se percebeu como parte da elite política de sua região, aceitando em 1990 ser candidato a viceprefeito em uma legenda encabeçada por um político que possuía uma aprovação popular muito menor que a sua. Naquela época ${ }^{33}$ ele se definia como alguém "querido pelo fato de ter a cara de seu povo"34. Inexistia em Joca nesse momento a percepção de que a distância entre ele e os demais políticos residia exatamente no fato de ser ele "parte do povo".

O período em que ocorre a definição de candidatos à Prefeitura de Belford Roxo equivale a uma modificação na maneira como Joca encara-se. A percepção de que seu apelo popular tende a transformá-lo em um objeto eleitoral por parte de pretensos candidatos "naturais" pertencentes à tradicional elite política local faz com que procure, finalmente, um espaço político próprio. Tal busca o conduz a outra migração partidária

\footnotetext{
${ }^{33}$ O Jornal de Hoje editado no dia 13 de abril de 1990 discute sobre os nomes que participariam das eleições municipais excepcionais que ocorreriam em outubro daquele mesmo ano. Joca empenhara sua palavra a Ediraldo Matos e seria o seu vice. Enfatizava o jornal, entretanto, que Joca seria muito mais feliz se fosse o candidato a prefeito. Alegava o jornalista possuir indicações de que, independente do candidato à Prefeitura, se Joca fosse o vice, a candidatura seria vitoriosa (Jornal de Hoje, 13 abr. 1990, p. 03).

${ }^{34}$ Jornal de Hoje, 13 abr. 1990, p. 03.
} 
e ele, que havia trocado o PMDB pelo $\mathrm{PDT}^{35}$, agora resolve que o PDT - partido que tem em Laerte Bastos ${ }^{36}$ um "candidato natural" - deve ser substituído pelo Partido Liberal $[\mathrm{PL}],{ }^{37}$ troca que ocorreu em 1991.

A submissão à elite política local a que Joca sujeitara-se até aquele momento finaliza-se com um rompimento radical que gerou grande parte dos seus inimigos políticos. A partir daí e durante toda a campanha, os grupos que antes o cortejavam passam a opor-se a todas as suas ações. As acusações de participação em grupos de extermínio, assaltos, tráfico de drogas e em quadrilhas de aparas ${ }^{38}$ de cargas roubadas transformamse por essa época em processos e o antigo líder comunitário deixa de ser reconhecido pela imprensa unicamente como "um homem do povo" para ser considerado também como um dos principais "chefes de grupos de extermínio da Baixada".

Deve-se ter em mente que o elenco de acusações que pesaram sobre o prefeito nunca foram provadas e, muito embora para a realização deste trabalho tenhamos nos deparado com entrevistados que garantiram terem assistido execuções realizadas com a participação de Joca, no seu conjunto os depoimentos e as matérias de periódicos locais indicam uma aproximação de Joca com grupos de exterminadores. Participações indiretas prevalecem como testemunhos mais frequentes em entrevistas, ou seja, pessoas que conviveram com Joca em diferentes períodos de sua vida lembram que ele era amigo de exterminadores e que não condenava tal prática, pelo contrário, considerava necessária e bem-vinda a morte de elementos socialmente problemáticos. ${ }^{39}$ Até nessas considerações

${ }^{35}$ Dentro do qual permaneceu somente cinco meses provavelmente com a finalidade de aproximar-se do prefeito de Nova Iguaçu, Aluisio Gama.

${ }^{36}$ Laerte Bastos: político militante do PDT. Antes do fenômeno Joca, era o líder político mais popular de Belford Roxo. Migrante também, a sua carreira política notabilizou-se a partir da sua participação em grupos responsáveis pela organização de trabalhos comunitários destinados à construção de casas em mutirão. Participante das Ligas Camponesas, acabou sendo preso e torturado durante o regime militar. Foi o segundo colocado nas eleições municipais que consagraram Joca, sendo naquele momento deputado federal e vice prefeito de Nova Iguaçu (Jornal de Hoje, 21 maio 1992).

${ }^{37}$ Joca consegue eleger-se como primeiro prefeito de Belford Roxo em 03/10/1992, sendo o candidato de uma frente de partidos que incluía, além do Partido Liberal (PL), o Partido da Social Democracia Brasileira (PSDB), o Partido da Frente Liberal (PFL), o Partido Democrata Cristão (PDC), o Partido Trabalhista Brasileiro (PTB) e o Partido Democrático Social (PDS) (Jornal de Hoje, 11 out. 1992, p. 05).

38 Na linguagem policial dá-se o nome de "apara" ao ato de receptar carga roubada. A promotora Tânia Maria Sales Moreira, que investigava a ação dos grupos de extermínio na Baixada, apontou Joca em 1985 como chefe de grupo de extermínio e receptor de cargas roubadas. Entretanto ele nunca foi a julgamento devido à falta de provas (Jornal de Hoje, 22 jun. 1995, p. 03).

${ }^{39}$ A ideia de que Joca fosse o chefe de um grupo de extermínio parece ter se propagado com mais força a partir das acusações do policial Joel Gomes Leal, morto em 1993 por ação de grupos de extermínio. Este policial foi o responsável pela prisão de Jorginho da Farmácia, Cosminho, Saul e Du Boi, condenados em 1989 por serem os autores de algumas chacinas ocorridas durante a década de 1980 no distrito de Belford Roxo. Para esse policial, que era também presidente local de um partido político de oposição a Joca e tivera a sua candidatura à Prefeitura "fritada pelos articuladores da campanha de Joca", o primeiro prefeito era o chefe dessa quadrilha (Jornal do Brasil, 13 out. 1992, p. 13). 
não existem diferenças em relação ao que geralmente a população dos bairros mais pobres da Baixada pensam.

Novamente Joca destaca-se pela sua proximidade com o que chamava de "seu povo", podendo-se entender que ele incentivava as ações de justiçamento. De qualquer maneira as acusações de participação em grupos de extermínio e em receptação de cargas roubadas mais frequentes nos jornais locais a partir da saída de Joca do PDT e de sua entrada no PL servem para mostrar os efeitos de um rompimento entre Joca e a elite política local.

Serem verdade ou não tais acusações é algo pouco relevante na medida em que o que importa para nós é entender de que maneira ocorria a interação entre Joca e a população de Belford Roxo.

\section{4. "O governador da Baixada" governando}

Uma das primeiras aparições públicas de Joca como prefeito foi para, juntamente com um grupo de fiscais improvisados, fechar estabelecimentos comerciais em que as licenças de funcionamento não estivessem pagas. Recheadas com fotos do próprio prefeito lacrando lojas, as edições de jornais regionais do dia seguinte anunciavam a inauguração de um "novo tempo". 40

Comparado com o tempo anterior, este se diferenciava pela observância de regras básicas, como a fiscalização do pagamento de impostos, o condicionamento de novas construções à liberação de plantas na prefeitura e ao pagamento de taxas, e, principalmente, à extensão dos serviços públicos básicos à parte mais pobre da população belford-roxense. Caminhões destinados a recolher detritos passaram a rodar por Belford Roxo todos os dias, muros pintados nas cores do novo município (azul e branco), não receberam mais pichações, ativaram-se antigos postos de saúde e anunciou-se para breve a construção de outros postos e de um moderno hospital. Prometeu-se a construção de um batalhão da polícia militar e de mais escolas.

Promessas, entretanto, não eram o forte de Joca e por isso ele se apressou em desapropriar terrenos baldios do centro e de bairros mais populosos que abrigavam lixeiras, transformando-os rapidamente em praças com brinquedos. Uma grande quantidade de ruas recebeu saneamento e pavimentação e, para que fosse diminuída a periculosida-

40 Jornal de Hoje, 03 jan. 1993, p. 09. Correio de Maxambomba, 05 jan. 1993. 
de do trânsito, instalaram-se diversos redutores de velocidade no centro do município. Enfim, a população tinha motivos para surpreender-se ante a enxurrada de benfeitorias que de repente caía sobre Belford Roxo.

O centro, marcado pela eterna sujeira, pelas inundações frequentes e pelo desrespeito ao espaço público ganhou uma grande área de lazer, permanecendo limpo e conservado. Nos bairros, o recolhimento do lixo, as obras de saneamento e as promessas de novos colégios e de melhoria do serviço de saúde e segurança alimentavam as esperanças da transformação de Belford Roxo em uma "cidade-modelo". Para além disso tudo, desabavam os índices de violência, excetuando-se aí o número de homicídios que aumentaram sensivelmente principalmente morrendo pessoas através de chacinas nitidamente caracterizadas, segundo a polícia, como obra de justiceiros. ${ }^{41}$

Joca assumiu a Prefeitura de Belford Roxo em primeiro de março de 1993. Para alguns entrevistados que o conheceram bem antes da época em que era prefeito, ele por essa época não lembrava mais o "líder comunitário" de 1983 ou o vereador que em 1989 entendia, apesar do amplo apoio popular, não ser qualificado o suficiente para assumir a Prefeitura de seu município. Ele era, em certos aspectos, o contrário de tudo o que havia sido até ali:

O poder subiu a sua cabeça. Reclamava o tempo todo da preguiça de todo mundo. Visitava colégios municipais para fiscalizar o trabalho das professoras e, às vezes, humilhava algumas em público. Chegava em postos de saúde antes de todo mundo e ficava esperando para ver se os médicos chegariam tarde. Fazia questão de acompanhar a fiscalização quando dava blitz no comércio. Ele mesmo lacrava as portas das lojas. Irritava-se com qualquer opositor e chegou a bater na cara de um vereador aqui na praça, na frente de todo mundo. ${ }^{42}$

O comportamento agressivo era explicado por Joca da seguinte maneira: "Não existia melhor opção que ele para Belford Roxo", 43 o que fazia com que considerasse “Belford Roxo um 'brinquedo' seu". ${ }^{44}$ Entendendo-se como a única esperança de salvação para o caos que era o seu município, Joca se notabilizaria pelo estabelecimento de símbolos que vinculavam sua imagem pessoal ao seu "brinquedo": o símbolo de sua campanha à Prefeitura havia sido um coração. Esse símbolo pessoal passará a ocupar o

\footnotetext{
${ }^{41}$ Jornal de Hoje, 20 mar. 1993, p. 09; 18 ago. 1993, p. 05; 15 nov. 1993, p. 10; Correio de Maxambomba, 18 maio 1993, p. 03; 17 dez. 1993, p. 02.

42 SILVA, Odmar da. Entrevista Concedida em 28 nov. 1995.

43 Idem.

${ }^{44}$ Idem.
} 
centro do Brasão do município - que é um coração envolto por correntes e uma mensagem que lembra o slogan de campanhas eleitorais de Joca: "Paz e progresso" -, as laterais dos pontos de ônibus mandados construir por Joca e um monumento no centro do novo município.

A estreita vinculação entre Joca e Belford Roxo é, entretanto, melhor entendida quando lembramos o fato de o prefeito ter mandado gravar um coração em um de seus dentes de ouro e de ter encomendado um hino oficial que apresentava como tema não o passado ou as características naturais ou econômicas de seu município, como tradicionalmente se faz, porém a sua figura comparada no hino a um salvador heróico e solitário:

Ele chega carregando uma bandeira / Traz o símbolo da 'paz e liberdade' / Sobe morro, desce morro / Dia-a-dia sem parar / À procura de crianças para ajudar / Olha ele aí, olha ele aí / Sempre ao lado de Deus / Fazendo esse povo feliz / Joca, Joca / Amigo de ontem / Amigo de hoje / Amigo de sempre ${ }^{45}$

Ao lado da ampla aprovação popular, acusações sucediam-se: agora ele não era somente o receptador de cargas roubadas e líder de grupos de extermínio. Também era um voraz consumidor das verbas municipais que encarava como seus recursos pessoais. Alguns inimigos mais corajosos destacavam ser a grande quantidade de automóveis exibidos por Joca e por seus parentes mais próximos incompatível com uma administração honesta, e alguns vereadores reclamavam o fato de não poder existir oposição à pessoa do prefeito e ao seu governo, entendimento que fez com que a casa de alguns deles se transformasse em alvo de atentados em vésperas de votações de projetos importantes para o prefeito. ${ }^{46}$

A cooptação dos vereadores belford-roxenses não se fez, entretanto, sempre sob uma chuva de balas: em pouco tempo Joca conseguiu eliminar grande parte da oposição que se fazia a ele de uma maneira que distingue o governo Joca dos antigos governos iguaçuanos, ao mesmo tempo em que nos possibilita pensar nesse governo como o estabelecedor de um padrão de gestão levada adiante pelos líderes marginais da região da Baixada Fluminense.

\footnotetext{
45 Três últimas estrofes de "Mensagem ao tio Joca", Hino Oficial do Município de Belford Roxo. Jornal de Hoje, Edição de Belford Roxo, 12 nov. 1993 entre os anos de 1993 e 1995. p. 09. Após sua morte, o Hino Oficial do Município de Belford Roxo deixou de ser o "Mensagem ao tio Joca", passando a referirse a fatos históricos ligados ao antigo distrito de Belford Roxo.

46 T.M. Entrevista Concedida em 12 set. 1995.
} 
Não muito depois do início de seu governo, o prefeito negociou com vários empresários belford-roxenses a fim de definir um plano que deveria servir de base para a "reconstrução de Belford Roxo", 47 plano esse que não deveria somente levar em consideração as verbas municipais, mas que deveria contar com a participação de todos os empresários interessados em obter o apoio do governo municipal, potencial garantidor de uma expansão econômica dentro do município. Seguindo o discurso de Joca na reunião que encerrou tais negociações, a existência de oposição era indesejável, uma vez que pouco prática, propiciando unicamente um excesso de discussão que emperrava o prosseguimento das medidas emergenciais propostas e efetivadas por Joca. Portanto, cada um dos empresários deveria preocupar-se em doar ao município o que estivesse dentro das suas condições a fim de permitir à nova Prefeitura manter o enorme canteiro de obras em que se transformara o antigo distrito iguaçuano.

A multinacional Bayer do Brasil, maior empresa privada da região, ficou encarregada de organizar a defesa civil municipal, fornecendo para isso sua brigada interna de bombeiros e doando à Prefeitura as viaturas que serviriam ao novo município. Além disso, os vasilhames destinados a abrigar temporariamente o lixo de todo o município tinham como origem essa multinacional que pintava seus tambores de produtos químicos vazios com as cores do novo município e os espalhava por todos os bairros.

A cooperação entre as empresas e a Prefeitura tornou-se essencial para que Joca se mantivesse como o mestre de obras que se revelou durante todo o seu curto governo.

A parceria com as empresas presentes no munícipio parece ter inspirado Joca no caminho de transformar a Câmara de Vereadores em sua aliada incondicional. Aliás, foi algo facilitado pelo fato de que esse primeiro legislativo era formado quase exclusivamente por representantes de grupos de bairros, dos quais os vereadores dependiam na medida em que "faziam o trabalho social" - auxiliando o que chamei acima de rede de resolução de problemas práticos -, o que os caracterizava, portanto, como representantes distritais diversos de um simples vereador.

\footnotetext{
47 A Associação Comercial e Industrial de Belford Roxo (ACIBER), mesmo antes da posse de Joca, já contribuía com o governo do novo município encomendando ao Instituto Brasileiro de Administração Municipal (IBAM) um projeto que quantificava o que todos já sabiam: Belford Roxo era um município que nascia com fontes de renda definidas, porém apresentava uma quantidade enorme de problemas relacionados principalmente ao crescimento desordenado da população que terminou por levar a uma péssima ocupação do solo urbano e ao desaparecimento da pouca infraestrutura existente no antigo distrito iguaçuano. Em seu discurso de agradecimento, o prefeito eleito enfatizou a necessidade de realizar um governo integrado no qual os empresários e as associações de moradores deveriam participar de forma efetiva a fim de construir um município forte (Jornal de Hoje, 20 set. 1992, p. 07).
} 
Nada melhor para Joca que o loteamento dos bens públicos municipais, transformados em moedas utilizadas largamente na compra da fidelidade dos vereadores. Dividindo o município em áreas de atuação, o vereador - conforme a sua potencial fidelidade ou a sua condição econômica - receberia escolas, postos de saúde e ambulâncias que deveriam ser usadas unicamente no atendimento de necessidades da população dos bairros responsáveis pela sua eleição.

Tal prática transformava os primeiros vereadores belford-roxenses em clientes políticos de Joca extremamente preocupados em debelar qualquer sombra de oposição ao líder do Poder Executivo municipal. Jogada de mestre que possibilitava ao novo prefeito dividir suas responsabilidades e carrear para si louros de uma espécie de trabalho de assessoria realizado pelos vereadores.

É possível pensar que a estratégia imaginada e posta em prática por Joca elimina grande parte da oposição existente na Câmara Municipal. Não significa isso que ele não continue acumulando desafetos entre a antiga elite política regional e até entre membros de associações de moradores. Característica desse movimento de criação de inimigos foi sua reação à ausência da população de um determinado bairro em uma reunião marcada por ele na Associação de Moradores. Irado pela ausência dos "principais interessados", os chamará de preguiçosos e dirá que, se fosse para fumar maconha ou cheirar cocaína, todos estariam ali. ${ }^{48}$

O talento para criar inimigos políticos é responsável por diversas versões populares para sua morte violenta. A conspiração surgia como motivo recorrente para explicar essa morte. Dizia-se que ele fora morto a mando do governador Marcello Alencar que estaria preocupado com o crescimento da sua importância política. Também havia a versão de que sua mulher mandara matar Joca com a finalidade de apropriar-se de toda a riqueza que ele acumulara como prefeito de Belford Roxo.

Apesar de suas estratégias de cooptação, vereadores recalcitrantes mantêm-se na Câmara Municipal, porém sua oposição não sensibiliza a população espantada com a substituição do seu tradicional trabalho de autoconstrução pelo papel de "fiscais da Prefeitura" que Joca passa a atribuir à população de Belford Roxo. Característico desse novo papel desempenhado pelos belford-roxenses é o seguinte diálogo mantido entre um morador e a prefeita de Belford Roxo, Maria Lúcia, esposa de Joca:

\footnotetext{
${ }^{48}$ SILVA, Odmar da. Entrevista Concedida em 28 nov. 1995.
} 
- Prefeita, não adianta jogar asfalto. A tubulação de escoamento tem um diâmetro ridículo. Vai tudo encher novamente na primeira chuva. Quando o falecido (Joca) passava aqui a gente falava e era ouvido numa boa. Agora a senhora fica toda alterada. Eu sei que a senhora é boa, mas é preciso ouvir o povo".

Maria Lúcia devolve:

- Vocês é que são meus fiscais. Por que não mandou parar a obra?. ${ }^{49}$

Acabam surtindo efeito inverso do esperado as acusações de seus oposicionistas na medida em que acusar Joca de corrupto não demove os belford-roxenses, sobremaneira interessados em justificar todos os atos do seu líder providencial.

Os para-choques das inúmeras ambulâncias que Joca mantinha como veículos essenciais do seu serviço social ostentavam a seguinte frase: “O senhor é meu pastor e nada me faltará". ${ }^{50}$ Encontramos também outro versículo capaz de expressar melhor a maneira escolhida pelo primeiro prefeito para conduzir sua vida política e seu governo: "Ainda que eu andasse pelo vale da sombra da morte mal nenhum temeria...". 51

Os dois anos e três meses do governo Joca caracterizaram-se pelo extremismo, especializou-se ele em manter holofotes apontados em sua direção. Tendo diante de si um município pequeno, densamente povoado, possuidor de diversas fábricas e de uma atividade comercial média quando comparada a outros municípios da Baixada, ${ }^{52}$ Joca demonstrou saber desde o primeiro dia de mandato que a última necessidade de sua gente era possuir um prefeito burocrático tal como os antigos mandatários de Nova Iguaçu, alguns dos quais eleitos com amplo apoio desse antigo distrito.

Inexistindo leis e funcionários necessários à burocracia municipal, Joca iniciou seu governo de uma maneira improvisada, marcada pela atuação direta. Ele supervisionava pessoalmente as diversas obras emergenciais como a eliminação dos vazadouros clandestinos de lixo, a pintura dos muros das cidades e a intimidação aos principais pichadores que residiam em alguns dos morros localizados no centro da cidade. ${ }^{53}$

\footnotetext{
${ }^{49}$ Veja Rio, 09 abr. 1997, p. 10.

${ }^{50}$ Livro de Salmos, capítulo 23, versículo 01.

${ }^{51}$ No mesmo salmo acima citado, o versículo 04.

${ }^{52}$ Belford Roxo em 1990 possuía 376.000 habitantes espalhados em 73 Km². Segundo a Associação Comercial e Industrial de Belford Roxo (ACIBER), em setembro de 1992 existiam 400 instalações industriais no município.

53 "Subiu no morro e foi falar direto com o chefe do tráfico. Disse que não interferiria no comércio dele desde que ele conseguisse manter a paz por aqui. Perguntou quem eram os pichadores e mandou recado pelo líder do tráfico: a partir daquele dia quem sujasse qualquer prédio na cidade teria de conversar com ele. Acabaram as pichações" (ADF. Entrevista Concedida em 02 set. 1995).
} 
Suas ações iniciais tiveram como marca principal a percepção de que tudo estava para ser feito e de que sua missão fundamental era criar um poder público que pudesse ser definido como presente. Com essa finalidade tornava-se necessário obter impostos driblando de imediato a primeira grande dificuldade apontada pela Prefeitura iguaçuana que estimava ser de mais de $70 \%$ o índice de inadimplência no município. ${ }^{54}$ Cônscio disso Joca iniciou o esforço no sentido de, por exemplo, regularizar todas as construções, uma vez que os governos iguaçuanos nunca exigiram tal, criando uma situação estranha em que oficialmente os prédios inexistiam, pagando por isso unicamente impostos territoriais. O conhecimento dessa situação inspirou sua primeira grande ação pública como prefeito: fechar o comércio irregular e multar as diversas construções não informadas à Prefeitura.

Arrecadar fundos, abandonar quotidianamente seu gabinete a fim de acompanhar a realização das obras que inauguravam o novo município passam a ser marcas do governo Joca, conseguindo ele não somente juntar em torno de si o apoio dos belfordroxenses, mas também a admiração da população de outros municípios da Baixada Fluminense, o que fez com que seu estilo de governo passasse a ser exemplar para os demais prefeitos dessa região, contaminando-se de forma definitiva os distritos restantes de Nova Iguaçu com a ideia de que, somente através das emancipações distritais e da eleição de líderes identificados com as necessidades populares, seria possível resolver os graves problemas decorrentes das omissões representadas pela Prefeitura de Nova Iguaçu.

Muito mais que um hábil manipulador de corações e mentes da população do seio da qual se destacou, Joca deve ser lido como o produto de um meio de cultura cultivado pelos próprios belford-roxenses. Ele foi, portanto, um parceiro de seu "povo" no estabelecimento de uma alternativa ao desprestígio da massa belford-roxense ante os organismos oficialmente representativos das diversas esferas do poder estatal. Embebido de seu sucesso popular ele entregou-se a essa população pauperizada habitante de Belford Roxo, transformando-se em uma espécie espetacular de herói salvador político mesmo antes de localizar-se no posto máximo do município ao qual ajudou construir.

\footnotetext{
${ }^{54}$ No Correio de Maxambomba de 10 de setembro de 1995. o prefeito Altamir Gomes, de Nova Iguaçu, afundado no que ele chamou de a pior crise vivida por Nova Iguaçu, desabafou: "A prefeitura não tem condições de sustentar-se. Nenhum governo até hoje preocupou-se em verificar quantos moradores pagam os seus impostos. Nossos levantamentos apontam para uma inadimplência de mais ou menos $70 \%$, e nesse exato momento estão construindo mais casas que nós sequer sabemos que existem. Com as emancipações ficamos com todos os funcionários e perdemos metade da receita. Não temos condições de sobreviver."
} 
No dia 6 de julho do ano de 1962 a população da Baixada Fluminense fez a sua estreia nos periódicos cariocas. Tal estreia deveu-se aos vários episódios do dia anterior que ocorreram em parte do que hoje é a Região Metropolitana do Rio de Janeiro, mas que deixaram marcas mais profundas na Baixada Fluminense. Tratou-se do que foi chamado pelos jornalistas da época de quebra-quebra e - para os que analisaram os fatos naquele momento - deveu-se à ocorrência de uma greve geral e a uma crise de abastecimento de gêneros alimentícios que parece ter catalisado uma situação de carestia que atingia em cheio homens, mulheres e crianças das classes subalternas que enchiam a Baixada Fluminense, diretamente vindos dos "interiores do país" ou se derramavam ali a partir do contínuo processo de expulsão das favelas cariocas acentuado pelas autoridades militares alguns anos após quando a "revolução" de 1964 seria vitoriosa.

Antes desse momento a população da Baixada surge nos periódicos unicamente como personagem coadjuvante, por exemplo, do excêntrico deputado Tenório Cavalcanti ou de um bandido medonho o suficiente para chamar atenção dos jornais. No entanto, em 5 de julho de 1962 o papel principal coube ao "povo da Baixada", que, pela manhã logo, concentrado nos centros comerciais dos municípios dali, viu frustradas suas chances de chegar aos locais de trabalho na Guanabara devido à inexistência de meios de transportes paralisados todos devido à greve geral e que, sentindo o estômago "roer" devido à fome provocada pelos baixos salários e pela inexistência de gêneros de primeira necessidades nos mercados, atacou as casas comerciais dessas cidades, não somente saqueando os estoques de alimentos, mas também incendiando várias lojas e destruindo símbolos da exploração como, por exemplo as balanças que sempre insistiam em não fornecer a quantidade suficiente de alimentos para matar a fome das famílias e que foram empilhadas no meio da rua e queimadas com o auxílio de querosene e álcool.

Durante o final da década de 1960 e as duas seguintes, "o povo da Baixada" frequenta também os jornais como personagem principal devido aos muitos episódios de linchamento rotineirizados ali. Na maioria dos casos as vítimas são massacradas após serem flagradas cometendo algum delito grave como furto ou estupro. Alguns casos chamaram mais atenção devido às vítimas serem o que os jornais da época chamavam de débeis mentais ou por expressarem opiniões diferentes daquelas detidas pela maioria. Nesses casos, unicamente, os periódicos nomearam os mortos e contaram suas histórias destacando-se a história do "velho" nordestino Augusto Lopes da Silva que foi amarra- 
do em um poste do miserável distrito iguaçuano de Morro Agudo e torturado pela multidão durante muitas horas devido ao fato de andar nu pelas ruas e tentar, sem as roupas, invadir algumas das toscas casas existentes e ameaçar atacar as mulheres.

Fotos dele preso a um poste manchado por seu sangue repetiram-se em edições diversas dos principais periódicos cariocas e, até ao final da década de 1970, serviram de exemplo da nova selvageria vinda do "câncer vizinho" que era a Baixada Fluminense, onde uma massa sem líderes e quase selvagem vingava-se da exploração e do abandono através daquilo que o jornalista Tim Lopes chamou "a (in)justiça pelas próprias mãos".

Entre 1968 e 1980 perto de 30 casos de linchamento ocorreram na Baixada por razões as mais variadas. Com exceção do caso de Morro Agudo - que terminou por inspirar o filme "Crueldade Mortal" dirigido por Luiz Paulino dos Santos em 1976 -, nenhum desses casos chamou muito a atenção seja porque as vítimas eram antecipadamente tidas como culpadas até por quem deveria investigar os homicídios, seja porque a opinião geral era a mesma do advogado que sugeriu em 1978 que os linchadores mereciam uma "medalha cunhada a ouro", seja ainda porque as autoridades - policiais ou não - pensavam como o prefeito Ruy Queiroz no ano de 1978 que, mesmo após o distrito de Belford Roxo ser apontado em um estudo da UNESCO como o lugar mais violento do mundo em 1976, observava, contra todos os fatos, que "Nova Iguaçu é uma cidade muito tranquila. (...) os crimes que acontecem por lá são brigas entre quadrilhas, o que não chega a preocupar a vida da cidade. (...) na Baixada há menos crimes que em Copacabana". 55

A estreia do "povo da Baixada" nos periódicos já chamou a atenção de diversos estudiosos, quase todos eles apontando para a violência como uma marca distintiva da vida dessas pessoas. Prefiro pensar que os saques aos mercados em 1962 e os linchamentos que marcaram os anos finais da década de 1960, toda a década de 1970 e parte dos anos 1980 revelam a quebra da invisibilidade social que era tão cara àqueles que desejavam esconder as aparas do processo de transformação econômica do país.

As páginas dos quatro grandes periódicos cariocas das décadas de 1960-1980 deixam escapar o espanto de quem assiste "o pior do Brasil" ali "a menos de uma hora do centro da Guanabara", do "centro intelectual” do país.

\footnotetext{
${ }^{55}$ Jornal do Brasil, 23 mar. 1978, p. 7.
} 
A massa provocadora de “(...) um movimento desordenado e sem líderes" que parece surgir do nada nas páginas do Jornal do Brasil do dia 6 de julho de 1962 para arrasar o comércio da Baixada Fluminense é a mesma considerada inculta e ignorante por votar em um "bandido" chamado Joca em 1992?

Dentro dos trinta anos que separam o quebra-quebra de 1962 e a eleição de Joca em 1992, a população "desenraizada" da Baixada Fluminense enraizou-se e aumentou consideravelmente, a economia regional diversificou-se bastante, porém a presença pública não foi capaz de eliminar o fato de os habitantes dos bairros periféricos dessa região continuarem a ser cidadãos-só, autoconstrutores tanto de suas precárias casas como dos tantos equipamentos necessários às realidades da vida urbana contida nos bairros derivados dos tantos loteamentos surgidos principalmente a partir dos anos 1950.

Diferentemente daquilo que sugerem as matérias sobre o "povo da Baixada" acima citadas, para olhares menos panorâmicos, menos rápidos e mais pacientes, os habitantes dos bairros periféricos da região surgem facilmente como criadores, ao longo dos anos de colonização proletária, de estratégias de convivência e amenização dos problemas diversos originários de uma ocupação não planejada e distante de quaisquer preocupações estatais. Aliás, a ocupação popular da Baixada Fluminense assemelhou-se, se olharmos para as ações dos agentes estatais, bastante a um processo de exclusão dos migrantes recém-vindos tanto de várias áreas agrícolas do Brasil como das favelas cariocas.

A história em que Joca é um personagem marcante, porém não isolado, é a história de mulheres, crianças e homens que, herdeiros de diversas desventuras não somente produzidas por eles, encontram soluções capazes de tornar possível a sobrevivência nesse local geograficamente tão próximo do centro da capital fluminense, porém extensamente habitado por entes propositadamente mantidos à distância das preocupações estatais até ao ponto de se transformarem em invisíveis.

\section{Referências bibliográficas}

ALVES, José Cláudio Souza. Dos barões ao extermínio: uma história da violência na Baixada Fluminense. Duque de Caxias: APPH-CLIO, 2003. 
BELOCH, Edith Maria. Loteamentos Periféricos: Algumas considerações sobre essa forma de moradia proletária. Dissertação (Mestrado em Planejamento Urbano). Programa de Pós-Graduação em Urbanismo. Universidade Federal do Rio de Janeiro, 1980.

BELOCH, Israel. Capa Preta e Lurdinha. Tenório Cavalcanti e o povo da Baixada. Rio de Janeiro: Record, 1985.

BOBBIO, Norberto. (org.). Dicionário de política. Brasília: UNB, 1986.

CANETTI, Elias. Massa e poder. São Paulo: Companhia das letras, 1995.

CARVALHO, Iracema Baroni de. Laranjas Brasileiras. Nova Iguaçu: Prefeitura Municipal de Nova Iguaçu, 1999.

CARVALHO, José Murilo de. Cidadania no Brasil: o longo caminho. 7. ed. Rio de Janeiro: Civilização Brasileira: 2005.

CAVALCANTI, Sandra Tenório. Tenório, Meu Pai. Rio de Janeiro: Global, 1996.

COSTA, Marta Bebianno. Loteamentos na periferia do Rio de Janeiro: Um espaço de luta. Dissertação (Mestrado em Planejamento Urbano). Pós-graduação em Planejamento Urbano, Universidade Federal do Rio de Janeiro, 1979.

ENNE, Ana Lucia Silva. "Lugar, meu amigo, é minha Baixada”: memória, representação social e identidade. 2002. Tese (Doutorado em Antropologia). Programa de Pós-graduação em Antropologia. Universidade Federal do Rio de Janeiro, 2002.

FERREIRA, Marieta de Moraes. A nova velha história: O retorno da história política. Estudos Históricos, Rio de Janeiro, vol. 5, n. 10, pp. 265-271.

FERREIRA, Marieta de Moraes. História Oral. Rio de Janeiro: Diadorim, 1994.

FERREIRA, Marieta de Moraes; AMADO, Janaína (Orgs.). Usos e abusos da história oral. Rio de Janeiro: FGV, 1996.

FORTE, José Matoso Maia. Memória da fundação de Iguassú. Rio de Janeiro: Tipografia Jornal do Comércio: Rio de Janeiro, 1933.

GEIGER, Pedro Pinchas; MESQUITA, Miriam Gomes Coelho. Estudos Rurais da Baixada Fluminense. Rio de Janeiro: IBGE, 1956.

GINZBURG, Carlo. A micro história e outros ensaios. Lisboa: Difel, 1991.

GIRARDET, Raoul. Mitos e mitologias políticas. São Paulo: Cia. das Letras, 1987.

GOMES, Ângela de Castro. Questão social e historiográfica no Brasil do pós-1980: notas para um debate. Estudos Históricos, Rio de Janeiro, FGV, n. 34, 2004.

GRYNSZPAN, Mario. Os idiomas da patronagem: um estudo da trajetória de Tenório Cavalcanti. Revista Brasileira de Ciências Sociais n. 14, ano 5, 1990.

KUSCHNIR, Karina. O cotidiano da política. Rio de Janeiro: Jorge Zahar, 2000.

LEI, Justiça e Cidadania. Rio de Janeiro: CPDOC-FGV/ISER, 1997. 
LESBAUPIN, Yves do Amaral. Direitos humanos e classes populares; os direitos na perespectiva de grupos populares do município de Nova Iguaçu. Dissertação (Mestrado em Sociologia). Programa de Pós-graduação em Sociologia, Instituto Universitário de Pesquisas do Rio de Janeiro, 1982.

LOUZEIRO, José. Mito em chamas: A lenda do justiceiro Mão Branca. São Paulo: Moderna, 1997.

MONTEIRO, Linderval Augusto. Baixada Fluminense, identidades e transformações: Estudo de relações políticas na Baixada Fluminense...2001. Dissertação (Mestrado em História Social) - Programa de Pós-graduação em História Social, Universidade Federal do Rio de Janeiro, 2001.

MONTEIRO, Linderval Augusto. Baixada Fluminense: ausência e informalidade. Soluções práticas da população baixadense a partir da ineficiência do poder público. $\mathrm{O}$ caso Joca. 1996. Monografia (Bacharelado em História), graduação em História, Universidade Federal do Rio de Janeiro, Rio de Janeiro, 1996.

MOREIRA, Tânia Maria Sales. Chacinas e falcatruas. Rio de Janeiro: Lúmen júris, [199-].

PEIXOTO, Ruy Afrânio. Imagens Iguaçuanas. Rio de Janeiro: sem editora, 1960.

PEREIRA, Waldick. A mudança da Vila. História iguaçuana. Nova Iguaçu: Prefeitura Municipal de Nova Iguaçu, 1997.

SANTOS, Carlos Nelson dos. Voltando a pensar em favelas por causa das periferias. Anais do Simpósio de Estudos do Planejamento Urbano e Habitacional. NEURB, PUC, Rio de Janeiro, 1978.

SEGADAS, Maria Terezinha. Nova Iguaçu: absorção de uma célula urbana pelo grande Rio de Janeiro. Tese (Livre-docência em Geografia), Faculdade Nacional de Filosofia, 1960.

SIMAS, Luiz Antônio. O evangelho segundo os jacobinos: Floriano Peixoto e o mito do salvador da república brasileira. Dissertação (Mestrado em História Social), Programa de pós-graduação em História Social, 1994.

WEFFORT, Francisco Corrêa. O populismo na política brasileira. São Paulo: Paz e Terra, 1980. 